Z. Oleksyn ${ }^{1}$, B. Naidych ${ }^{1}$, O. Chernikova ${ }^{2}$, Ł. Głowa ${ }^{3}$, Y. Ogorodnik ${ }^{4}$, M. Solovyov ${ }^{5}$, V. Vashchynskyi ${ }^{5}$, R. Yavorskyi ${ }^{1}$, G. Il'chuk ${ }^{5}$

\title{
First-Principles Calculations of Stable Geometric Configuration and Thermodynamic Parameters of Cadmium Sulfide Thin-Film Condensates
}

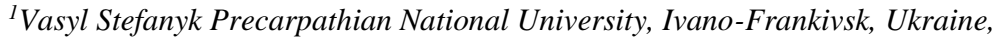 \\ bohdana.naidych@pnu.edu.ua \\ ${ }^{2}$ Kryviy Rih National University, Kriviy Rih, Ukraine, hmchernikova@gmail.com \\ ${ }^{3}$ Radiation Monitoring Devices, inc. USA, yogorodnik@ rmdinc.com \\ ${ }^{4}$ College of Natural Sciences, Rzeszow University, Pigonia 1, 35-959 Rzeszow, Poland \\ ${ }^{5}$ Lviv Polytechnic National University, Lviv, Ukraine
}

\begin{abstract}
Thin-film CdS layers obtained by the open evaporation in vacuum method are explored and cluster models for calculation of crystal, band structure and thermodynamic parameters are proposed. Thermodynamic parameters of the formation energy $\Delta E$, enthalpy of formation $\Delta H$, Gibbs free energy $\Delta G$, entropy $\Delta S$ and specific heat capacities at constant pressure $C_{P}$ and volume $C_{V}$ for cubic and hexagonal crystallographic modifications are calculated. A stable crystal structure for cadmium sulfide was determined from the analysis of temperature dependences of Gibbs free energies of sphalerite and wurtzite phases.
\end{abstract}

Keywords:.cadmium sulfide, crystal structure, wurtzite, thermodynamic properties.

Article acted received 21.03.2021; accepted for publication 15.06.2021.

\section{Introduction}

The development of photovoltaics in recent years is characterized by two trends: cheaper final photovoltaic systems (1) and increasing of energy conversion efficiency (2) [1]. Furthermore, these two issues are related. Therefore, many research groups are focusing on the study of film photovoltaic cells, which are increasingly competing with traditional silicon [2-3]. IIVI semiconductor group has potential applications in solar cell, light-emitting diodes and efficient thin film transistors [4]. Among thin-film systems, heterostructures of the CIS type [5-6], CIGS [7], CdTebased materials [8-10] have become the most effective. The expected effectiveness of the latter, in particular, reaches 28-30\% [11]. This is what causes the development of research on both heterostructures for photoelectric energy conversion and the study of technology, electrical, photoelectric, and structural properties of a separate layers of such heterosystems. After all, the current level of thin-film technology allows to specify the technological conditions for the formation of their structure and, in particular, the structure of surface nanoobjects, which also largely determine the properties of such layer [12].

CdTe-based structures are definitely interesting and one of the most relevant heterosystems [13]. CdTe-based films have the ability to generate and accumulate carriers perfectly. However, to increase efficiency, additional layers are added, which have their own unique properties. CdS is the materials that show the absorption in the ultraviolet (UV), visible and near-infrared (NIR) region and also shows optical nonlinearity, can be very useful in high harmonic generation, optical parametric oscillation, Kerr effect. CdS are found to exhibit absorption in the NIR region. The nonlinear susceptibility measurement on different CdS systems like nanoparticles, clusters, and nanocrystaline thin films of 
CdS are reported [14] In particular, the CdS layer, due to the large value of band gap, absorbs very well over a wide range of optical spectra [15]. However, this layer is combined with other materials, in particular $\mathrm{CdTe}$, due to the low ability to accumulate such a generated charge. That is why there are a large number of studies of different characteristics of the CdS/CdTe type heterosystem [16-18]. The efficiency of such systems is $15.8 \%$ at the $50 \mathrm{~nm}$ thickness of the CdS layer [19]. Accordingly, for such a small thicknesses, the basic properties will be determined by the structural characteristics of their surface.

The properties of a single $\mathrm{CdS}$ layer have been ivestigated in various studies. It should be noted that different technological approaches lead to different properties of the obtained $\mathrm{CdS}$ layer, and also differ in the different cost of obtaining such a layer. In particular, in [20] CdS layers were obtained by electrodeposition. In this paper, it is shown that by reducing the layer thickness below $50 \mathrm{~nm}$, electrodeposition technology leads to a deterioration in the efficiency of such a system. A layer of $100-150 \mathrm{~nm}$ in the g/FTO/n-CdS/nCdTe/p$\mathrm{CdTe} / \mathrm{Au}$ type structure is proposed as optimal. In [21] the CdS layers were obtained by magnetron sputtering to study their optical properties. The thickness of the layers was 200-400 nm. In [22] CdS thin films were obtained in a chemical bath, in particular, by the CBD method of thin film deposition. This shows a good consistency of the $\mathrm{CdS}$ and CdTe crystal structures, and also obtained the following characteristics: $\mathrm{J}_{\mathrm{sc}}$ of $14.7 \mathrm{~mA} / \mathrm{cm}^{2}, \mathrm{~V}_{\mathrm{oc}}$ of $100.53 \mathrm{mV}$ and FF of $27.7 \%$ is observed.

This paper proposes the study of the properties of the $\mathrm{CdS}$ layer obtained by the physical vacuum deposition method. Such technologies are quite simple and cheap. However, they make it possible to obtain individual layers with controlled characteristics of surface structure and optical parameters.

\section{Experiment}

Thin CdS films were obtained by open evaporation in vacuum on glass substrates. Technological modes of deposition are given in table 1 .

Table 1.

Technological factors of CdS condensate deposition in open vacuum on glass substrates. The substrate temperature was $473 \mathrm{~K}$, the evaporator temperature was $1153 \mathrm{~K}$.

\begin{tabular}{|l|l|l|}
\hline $\begin{array}{l}\text { Sample } \\
\text { number }\end{array}$ & $\begin{array}{l}\text { Deposition } \\
\text { time, } \tau, \mathrm{s}\end{array}$ & $\begin{array}{l}\text { Thickness } \\
\mathrm{d}, \mathrm{nm}\end{array}$ \\
\hline 1a & 90 & 560 \\
\hline $1 \mathrm{~b}$ & 90 & 560 \\
\hline $2 \mathrm{a}$ & 60 & 420 \\
\hline $2 \mathrm{~b}$ & 60 & 420 \\
\hline $3 \mathrm{a}$ & 90 & 540 \\
\hline $3 \mathrm{~b}$ & 90 & 540 \\
\hline $4 \mathrm{a}$ & 90 & 515 \\
\hline $4 \mathrm{~b}$ & 90 & 515 \\
\hline $5 \mathrm{a}$ & 150 & 1215 \\
\hline $5 \mathrm{~b}$ & 150 & 1215 \\
\hline
\end{tabular}

The thickness of the films was set by the deposition time and controlled by a profilometer.

\section{Ab initio modeling of crystal structure and electron distribution}

The current level of development of thin-film materials requires not only a constant experimental search for optimal synthesis conditions, but also a purposeful approach to their selection in order to obtain materials with predetermined parameters. In the theoretical description of such systems, it is necessary to take into account and describe the interaction between all electrons of a polyatomic system. It is quite complex, but the techniques are based on the density-functional theory [23-24] allow this to be done with high accuracy up to $1 \mathrm{kcal} / \mathrm{mol}$ and for large nuclear systems. Electron density is a fundamental characteristic of systems, it contains a significant amount of structural information, including data on the features of crystallographic fields and determines the various properties of molecules and crystals.

In this paper, we investigated the electronic properties of an impurity-free CdS (100) film applying the calculations from the first principles. The results were obtained using program code [25], which implements the Car-Parrinello quantum-mechanical dynamics with local approximation of density functional theory [26] and norm-preserving pseudopotential from the first principles of Bechelet, Hemenn, Schleter [27].

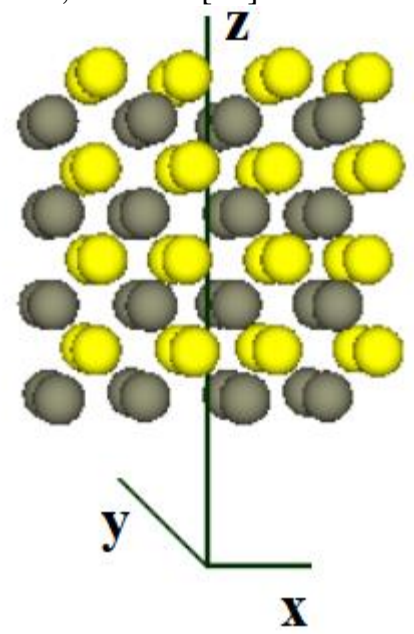

Fig. 1. Undoped CdS film.

To reproduce an infinite CdS film, an atomic basis of a primitive tetragonal superlattice cell was created, consisting of 64 atoms: $32 \mathrm{Cd}$ atoms, $32 \mathrm{~S}$ atoms, as shown in Fig. 1. The cell parameters were chosen to permit the modelling of an infinite surface of the film in the $\mathrm{X}$ and $\mathrm{Y}$ directions, and in the $\mathrm{Z}$ direction - free surfaces (100) with a passive coating.

Fig. 2 shows the cross sections of the spatial distributions of the valence electron density in mutually perpendicular planes (110) and (100) for CdS film without impurities with a viewing radius $5.8 \AA$. 


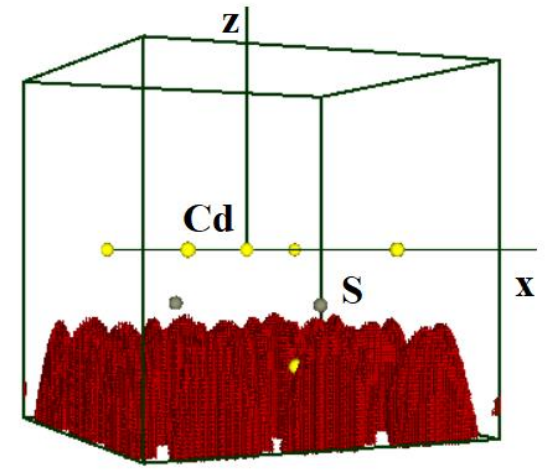

(a)
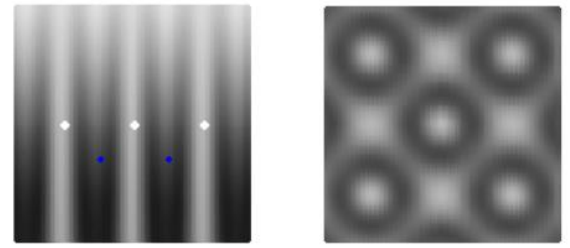

(б)

Fig. 2 Spatial distribution of the electron density of valence electrons for an impurity-free $\mathrm{CdS}$ film: (a) at $0.9-1.0$ of the maximum, the viewing radius is $5.8 \AA$; (b) cross sections of the spatial distribution of valence electrons in mutually perpendicular planes (110) and (100) for impurity-free CdS film.

We obtained the distributions of valence electrons by energy zones and their intersections in the planes (100) and (110) of the eight-layer impurity-free CdS film. The figure below (Fig. 3) shows the distribution of electrons in the energy zones for the $\Gamma$-state. In this case, the energy in atomic units is plotted on the horizontal axis, and the vertical - number of states per elementary energy interval. According to fig. 3, the minimum range of impurity $\mathrm{CdS}$ film corresponds to the value from $\mathrm{E}=-184.89$ a.u.e. to $\mathrm{E}=16.63$ a.u.e. with the maximum population of the states of the valence band 23 . The number of allowed states was determined by half the number of electrons (electron spin is not taken into

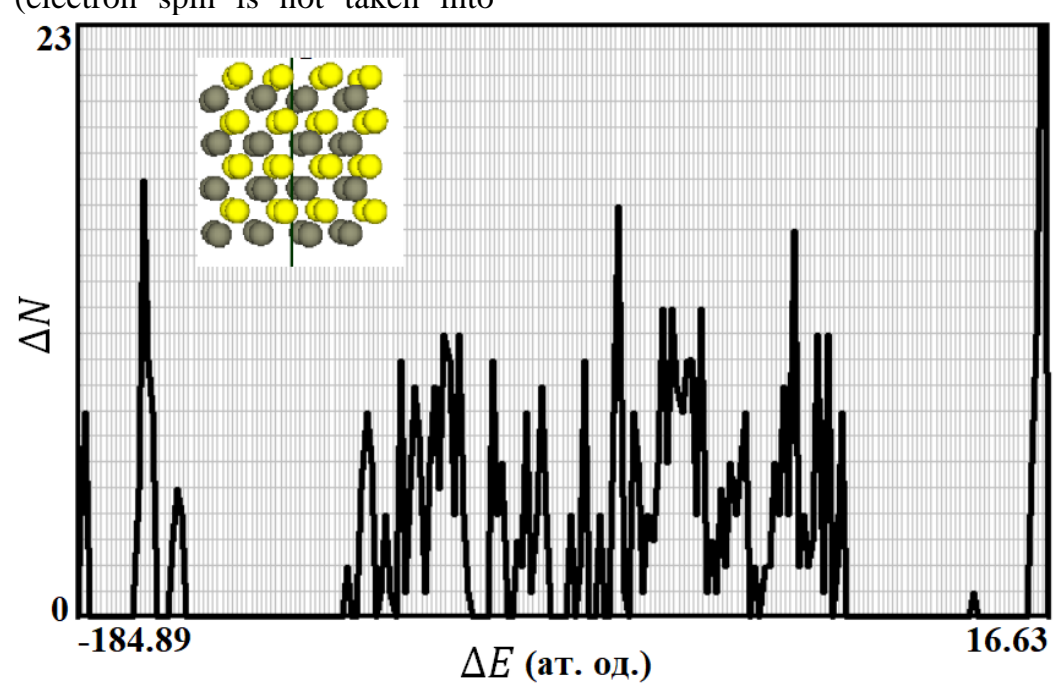

Fig. 3. Distribution of valence electrons by energy zones for impurity-free CdS film (100). The number of states is plotted on the vertical axis, and the energy range in atomic units is plotted on the horizontal axis.

\section{Calculation of thermodynamic parameters}

Since thermodynamic parameters of heat capacity, entropy, thermal expansion and Gruneisen parameter for semiconductors are related to other physical properties elastic and mechanical properties, it is critical to achieve accurate information of thermodynamic properties at certain pressure and temperature for fabrication and application of advanced semiconducting materials [4] The thermodynamic data of the clusters may be useful to estimate the direction of chemical reaction involved during their formation and also helps us to evaluate other thermodynamic functions according to Maxwell's thermodynamic relations [14].

The program code PC Gamess (US) [28] was used to calculate the thermodynamic parameters of the impurityfree solid-state $\mathrm{CdS}$ compound. The calculations were carried out using density functional theory, on the basis of Stevens-Basch-Krauss-Jasien-Cundari (SBKJC) [29] parameterization. In this basic set only the valence electrons which are directly involved in chemical bonding are considered. DFT calculations were performed by using Becke's three-parameter hybrid method [30] with Lee, Yang, and Parr (B3LYP) gradient corrected correlation functional [31].

In the sphalerite structure of $\mathrm{CdS}$, each atom of $\mathrm{Cd}$ or chalcogen ( $\mathrm{S}$ ) is located in the center of a regular tetrahedron, in the four vertices of which are the atoms of another element $\mathrm{S}(\mathrm{Cd})$, respectively. In this case, the chemical bond between $\mathrm{Cd}-\mathrm{S}$ atoms is due to the valence electrons Cd-5s $s^{2}$ and $S-3 p^{4}$.

In choosing the size and shape of the cluster, the purpose is to choose the optimal cluster size in terms of the balance between size and time spent on the calculation, given that with the increase in cluster size the stability of the system increases [14]. 
To calculate the thermodynamic parameters of the crystal structure of sphalerite, models of two clusters are proposed: "small" (Fig. 4, a) and "large" (Fig. 4, b).

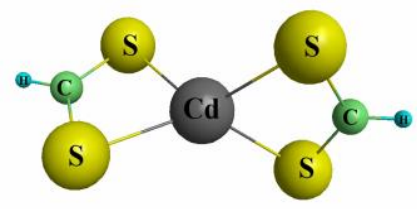

a)

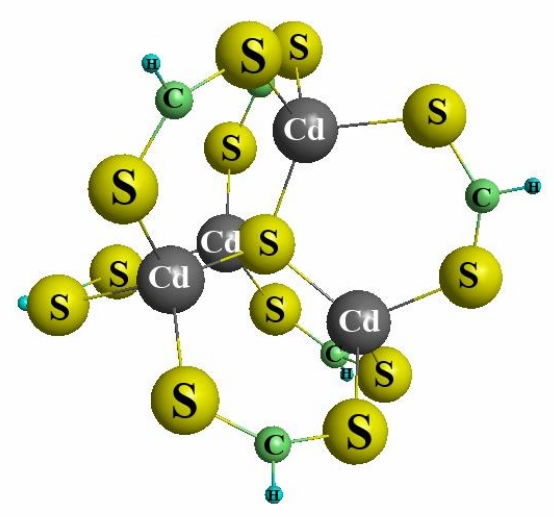

b)

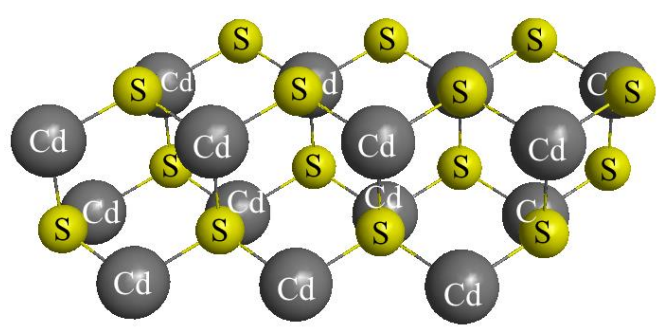

c)

Fig. 4. Models of clusters: $\mathrm{CdS}_{4} \mathrm{C}_{2} \mathrm{H}_{2}$ (a) and $\mathrm{Cd}_{4} \mathrm{~S}_{13} \mathrm{C}_{6} \mathrm{H}_{6}$ (b) for the cubic phase $\mathrm{CdS}$ and $\mathrm{Cd}_{15} \mathrm{~S}_{15}$ (c) for hexagonal modification.

In the "small" cluster of the sphalerite structure of $\mathrm{CdS}(\mathrm{Cd}+4 \mathrm{~S})$ the influence of the nearest neighbors of the boundary atoms is taking into account and realized by forming bonds of four electrons of carbon (C) atoms and one electron from hydrogen $(\mathrm{H})$ atoms, which corresponds to the formula $\mathrm{CdS}_{4} \mathrm{C}_{2} \mathrm{H}_{2}$ (Fig. 4, a).

The two clusters are selected so that from the calculated values for the "large", which corresponds to the formula $\mathrm{Cd}_{4} \mathrm{~S}_{13} \mathrm{C}_{6} \mathrm{H}_{6}$ (Fig. 4, b), the triple values for the ligands of the "small" cluster (Fig. 4, a) subtracts to obtain values only for the cadmium chalcogenide compound - CdS. Since the effect of ligands is insignificant (Fig. 4, b), such a contribution can be discarded in the calculation without significant loss of accuracy.

Using the values for the equilibrium positions of the atoms in the proposed clusters, the thermodynamic characteristics were calculated. When calculating $\Delta E$, $\Delta H, \Delta S, \Delta G$ used the following method of taking into account the initial conditions, which is shown by the example of the energy of formation $\Delta E$. Initially, the formation energy of cluster $\mathrm{A} \Delta E_{A}$ was calculated (Fig. 4, a) according to [32-33]:

$$
\Delta E_{A}=E-\sum E_{e l}+\sum E_{a t},
$$

where $\Delta E_{i}$ - energy of formation; $\mathrm{E}$ - total energy of the system; $E_{e l}$ - electronic energy of atoms that forming the system (in the atomic state); $E_{a t}$ - atomization energy. The total and electronic energy of the system were taken from the results of the calculation, as well $E_{a t}-$ from reference materials [34]. The formation energy of cluster B $\Delta E_{B}$ was calculated in a similar way (Fig. 4, b). After that, the triple value of formation energy of cluster A was subtracted from the formation energy of cluster B. I.e., from the amount of formation energy of the cluster, consisting of a sphalerite crystal fragment and six ligands (cluster b) the formation energy of ligands was subtracted:

$$
\Delta E=\Delta E_{B}-3 \cdot \Delta E_{A} .
$$

Cluster (a) consists of two ligands, so the calculations require triple values of the corresponding variables.

Based on the calculated vibrational spectra, the calculation of the thermodynamic characteristics of the $\mathrm{CdS}$ compound at different temperatures was performed (Fig. 5-6).

There is no need to involve additional atoms to fill the broken bonds to calculate the basic parameters of the wurtzite modification of the crystal structure. The cluster model consists of $30 \mathrm{Cd}$ and $\mathrm{S}$ atoms in equal proportions (Fig. 4, c). Then, to find the value of the thermodynamic parameter, the obtained values must be divided by 15 , since the model consists of 15 pairs of metal and chalcogen atoms.

\section{Results and discussion}

Table 2.

Dimensions of surface nanoformations of CdS / glass films. Technological parameters of deposition see in table. 1.

\begin{tabular}{|c|c|c|c|c|c|c|c|c|c|c|}
\hline $\begin{array}{c}\text { Dimensions, } \\
\mu \mathrm{m}\end{array}$ & $1 \mathrm{~b}$ & $1 \mathrm{~b}$ & $1 \mathrm{~b}$ & $2 \mathrm{~b}$ & $2 \mathrm{~b}$ & $3 \mathrm{a}$ & $3 \mathrm{a}$ & $4 \mathrm{a}$ & $4 \mathrm{a}$ & $5 \mathrm{a}$ \\
\hline & $10 \mathrm{kV}$ & $10 \mathrm{kV}$ & $30 \mathrm{kV}$ & & & & & & & \\
\hline & 1 & 2 & 1 & 1 & 2 & 1 & 2 & 1 & 2 & 1 \\
\hline Grains & $15-20$ & 10 & 20 & 30 & 30 & 50 & $30-40 \ldots$ & - & - & $>100$ \\
\hline Scales & 30 & 20 & 20 & 25 & $15-20$ & & & - & - & \\
\hline $\begin{array}{c}\text { Surf. nano- } \\
\text { objects }\end{array}$ & & & & & & 300 & - & - & \\
\hline
\end{tabular}


The sphalerite structure of $\mathrm{CdS}$ is stable at low temperatures and has a lattice parameter $\mathrm{a}=5.825 \AA$ [35]. In this paper the value of the lattice constant is obtained $6.1455 \AA$, which is relatively higher than the data [4] using the LDA - 5.816 $\AA$ та GGA - 5.990 $\AA$, due to the

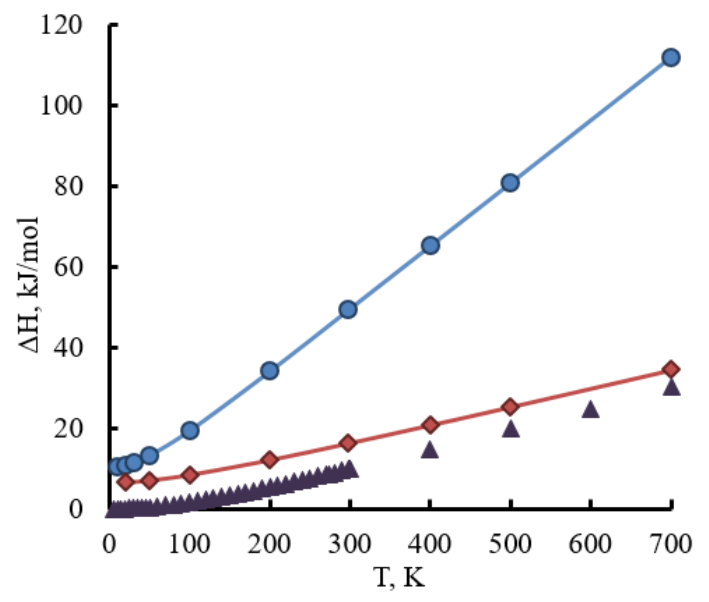

a)

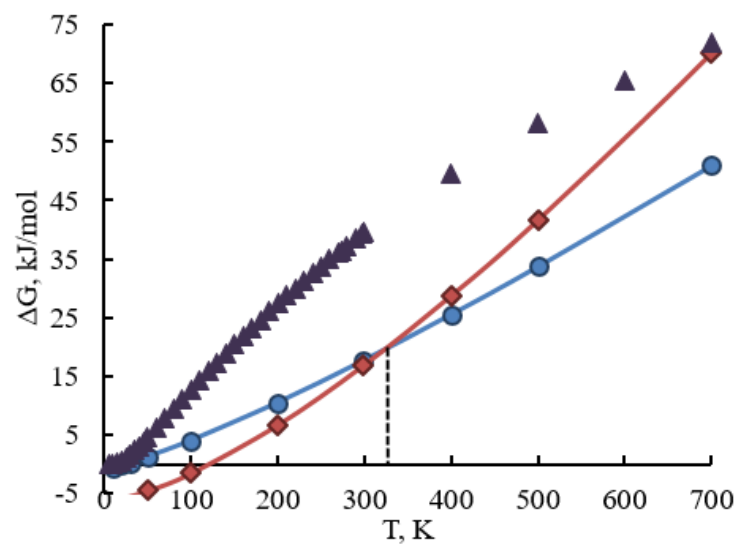

c) use of additional atoms for compensation of broken bonds. The wurtzite $\mathrm{CdS}$ structure has parameters $\mathrm{a}=4.138 \AA$ and $\mathrm{c}=6.718 \AA[36]$, and we obtained the value $\mathrm{a}=4.543 \AA$, and $\mathrm{c}=6.8758 \AA$.

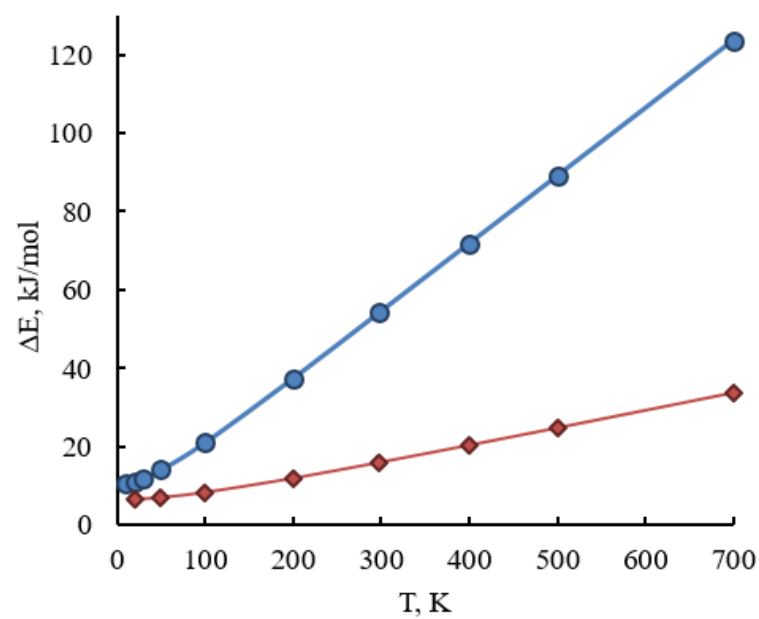

b)

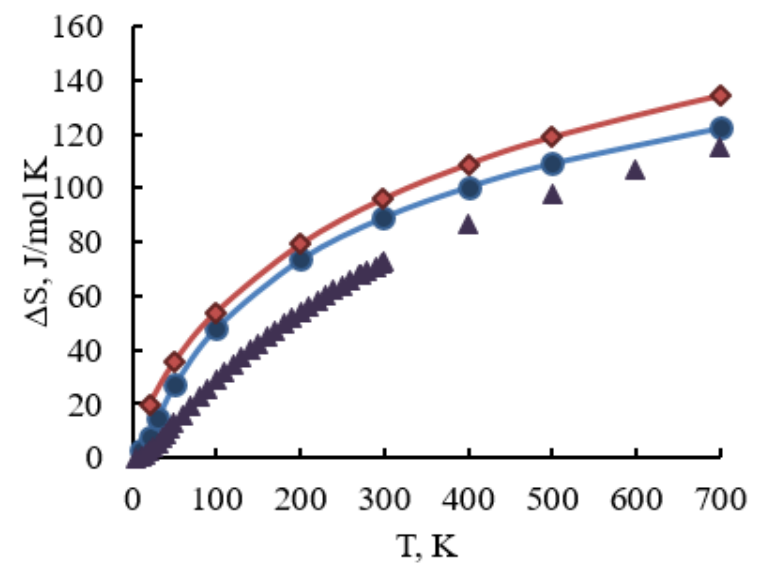

d)

Fig. 5. Temperature dependences of thermodynamic parameters: enthalpy of formation $\Delta H$ (a), formation energy $\Delta E$ (b), Gibbs energy $\Delta G$ (c) and entropy $\Delta S$ (d) for sphalerite $-\bullet$ and wurtzite $-\bullet$ CdS modifications and experimental data - $\boldsymbol{\Delta}[37]$.

Fig. 5 shows the change of formation energy $\Delta E$, enthalpy of formation $\Delta H$, Gibbs energy $\Delta G$ and entropy $\Delta S$ for sphalerite and wurtzite $\mathrm{CdS}$ crystals at temperatures from $10 \mathrm{~K}$ to $700 \mathrm{~K}$. Their analytical expressions can be represented by the dependences presented in table 3 .

When calculating the heat capacity for sphalerite crystal lattice, the triple value of the heat capacity of the smaller cluster was subtracted from the heat capacity of the larger cluster [32]. That is from $C_{V}\left(C_{P}\right)$ cluster consisting of a fragment of a $\mathrm{CdS}$ crystal and six ligands was subtracted $C_{V}\left(C_{P}\right)$ of ligands.

The CdS compound crystallizes in two modifications - cubic sphalerite lattice and hexagonal - wurtzite, which depends on the synthesis conditions and annealing temperature [38-39]. Then it is necessary to find theoretical values for the conditions of synthesis of the compound with specific crystalline modifications. As theoretical calculations [40], and experimental data from photoacoustic spectroscopy [41], High Resolution
XRD [42] indicate a sphalerite-wurtzite phase transition in the temperature range $523-573 \mathrm{~K}$. The wurtzite modification is more stable, as evidenced by the value of the Gibbs energy and the energy of formation [43].

Comparison of the values of Gibbs energies $\Delta G$ for sphalerite and wurtzite modifications indicates a transition from cubic to hexagonal modification at $320.74 \mathrm{~K}$. It should be noted that the data [44] indicate the existence of both phases at a temperature of $367.15 \mathrm{~K}$, so the ab initio methods quite accurately determines the temperature of the phase transition.

The calculated analytical expressions (Table 3) of the obtained temperature dependences of heat capacities at constant pressure and volume, respectively, which were approximated from quantum chemical calculation points using the Maple mathematical package, are described by the following temperature dependences (Fig. 6). 
First-Principles Calculations of Stable Geometric Configuration and Thermodynamic Parameters...

Table 3.

Coefficients $\left(a_{i}, b_{i}, c_{i}\right)$ of approximation of temperature dependences for thermodynamic parameters

$$
\Delta E(T)[\Delta H(T)]=a_{i} T+b_{i} ; \Delta G(T)=a_{i} \cdot 10^{-5} \cdot T^{2}+b_{i} T+c_{i} ; \Delta S(T)=a_{i} \ln (T)-b_{i} \text { and }
$$

$C_{V, P}(T)=a_{i}+b_{i} \cdot 10^{-3} \cdot T-c_{i} \cdot 10^{5} \cdot T^{-2}$ for CdS compounds at the temperature range $\mathrm{T}=(10-700) \mathrm{K}$.

\begin{tabular}{|c|c|c|c|c|}
\hline \multirow[t]{2}{*}{ Thermodynamic parameter } & \multicolumn{3}{|c|}{ Coefficients } & \multirow{2}{*}{$\begin{array}{c}\text { Crystal } \\
\text { modification }\end{array}$} \\
\hline & $\mathrm{a}_{\mathrm{i}}$ & $\mathrm{b}_{\mathrm{i}}$ & $\mathrm{c}_{\mathrm{i}}$ & \\
\hline \multirow{2}{*}{ Energy $\Delta E^{*}$} & 0.1653 & 6.3377 & & sphalerite \\
\hline & 0.0426 & 4.1641 & & wurtzite \\
\hline \multirow{2}{*}{ Enthalpy $\Delta H^{*}$} & 0.1487 & 6.337 & & sphalerite \\
\hline & 0.0434 & 4.1642 & & wurtzite \\
\hline \multirow{2}{*}{ Gibbs free energy $\Delta G^{* *}$} & 5 & 0.0468 & -1.1962 & sphalerite \\
\hline & 10 & 0.0496 & -7.2381 & wurtzite \\
\hline \multirow{2}{*}{ Entropy $\Delta S^{* * *}$} & 29.977 & 81.367 & & sphalerite \\
\hline & 35.094 & 98.694 & & wurtzite \\
\hline \multirow{2}{*}{ Heat capacity $C_{V} * * * *$} & 37.2622 & 29.9051 & 0.0371 & sphalerite \\
\hline & 33.478 & 15.733 & 0.0962 & wurtzite \\
\hline \multirow{2}{*}{ Heat capacity $C_{P} * * * *$} & 42.8054 & 29.9051 & 0.0371 & sphalerite \\
\hline & 34.3095 & 15.7329 & 0.0962 & wurtzite \\
\hline
\end{tabular}

$*[\Delta E],[\Delta H]:\left[b_{i}\right]=k J / \mathrm{mol},\left[a_{i}\right]=k J /(\mathrm{mol} \cdot K)$

$* *[\Delta G]:\left[a_{i}\right]=k J /\left(\mathrm{mol} \cdot K^{2}\right),\left[b_{i}\right]=k J /(\mathrm{mol} \cdot K),\left[c_{i}\right]=k J / \mathrm{mol}$

$* * *[\Delta S]:\left[b_{i}\right]=J /\left(\mathrm{mol} \cdot K^{2}\right)$

$* * * *\left[C_{V, P}(T)\right]:\left[a_{i}\right]=J / \mathrm{mol},\left[b_{i}\right]=k J /(\mathrm{mol} \cdot K),\left[c_{i}\right]=J /\left(\mathrm{mol} \cdot K^{2}\right)$

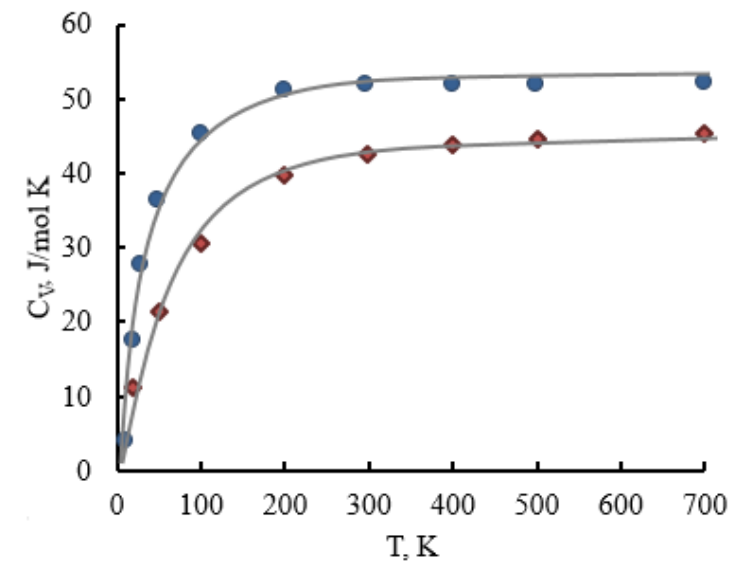

(a)

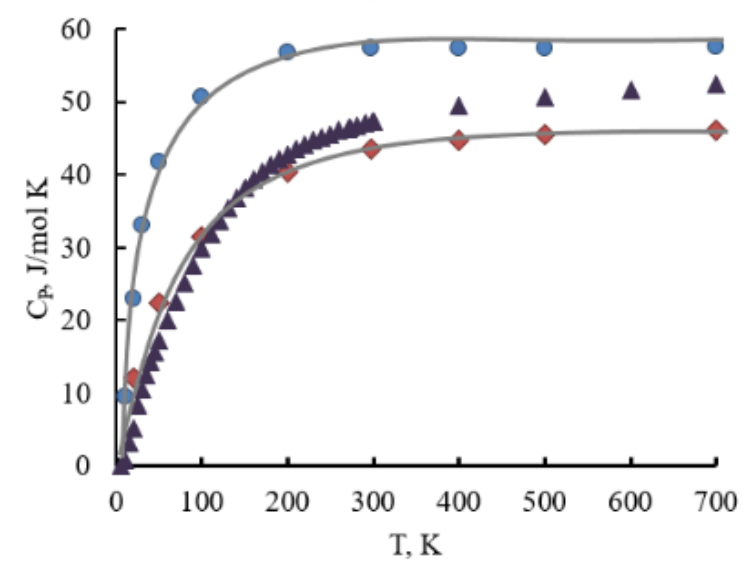

(b)

Fig. 6. Temperature dependences of specific heat capacity at constant volume $C_{V}$ (a) and pressure $C_{P}$ (b) for sphalerite $-\bullet$ and wurtzite $-\bullet \mathrm{CdS}$ modifications and experimental data $-\boldsymbol{\Delta}$ [37].
A good agreement of the calculated values of the specific heat at constant pressure for the hexagonal modification of the $\mathrm{CdS}$ crystal lattice with the experimental data [37] is obtained, which confirms the stability of the wurtzite phase. The need to attract additional atoms to compensate for broken bonds does not completely eliminate the effect of the contribution of free energy of broken bonds, which is manifested in the overestimation of the heat capacity of CdS clusters with a crystalline structure of sphalerite. In the generalized consideration of heat capacities it is possible to trace the regularity of behavior for binary compounds and subordination to Debye theory at low temperatures and stabilization at high, which corresponds to the theory of Dulong and Petit, although exceeding the values for cubic modification for the sphalerite phase.

\section{Conclusions}

1. Cluster models and boundary conditions for calculation of crystal structure, distribution of valence electrons by energy zones and thermodynamic parameters of $\mathrm{CdS}$ layers as a part of thin-film heterostructures are offered.

2. Temperature dependences of thermodynamic parameters for wurtzite and sphalerite phases of crystalline $\mathrm{CdS}$ are determined: energy of formation $\Delta E$, enthalpy of formation $\Delta H$, entropy $\Delta S$ and Gibbs energy $\Delta G$.

3. Analytical expressions for the temperature dependences of the heat capacity of cubic and hexagonal CdS crystals at a constant volume $C v$ and pressure $C_{P}$ are obtained from the first principles.

4. It is determined that the wurtzite modification is a 
more stable crystal structure in the region of medium and high temperatures for cadmium sulfide. The phase transition temperature for $\mathrm{CdS}$ is determined at $320.74 \mathrm{~K}$.

Part of this study was supported by the Ministry of Education and Science of Ukraine as the project for young scientists "Technology and computer simulation of optimized second generation photovoltaic systems based on compounds II-VI” (0121U108153).

leksyn Z. - Ph.D Student, Junior Researcher;

Naidych B. - Ph.D (Physics and Mathematics), Senior Researcher;
Chernikova O. - Ph.D (Physics and Mathematics), Senior Lecturer;

Gtowa $\mathbf{L}$. - Master of Science;

Ogorodnik Y. - PhD, Senior Researcher;

Solovyov M. - PhD (Physics and Mathematics), Research Assistant of Physics Department;

Vashchynskyi V. - Ph.D (Physics and Mathematics), Assistant of Physics Department

Yavorskyi R. - Ph.D (Physics and Mathematics), Researcher;

Il'chuk G. - Doctor of Physical and Mathematical Sciences, Professor.

[1] L. Nykyruy, V. Yakubiv, G. Wisz, I. Hryhoruk, Z. Zapukhlyak, R. Yavorskyi, Renewable Energy - Resources, Challenges and Applications. Chapter: Energy policy at the EU - non-EU border: critical analysis, opportunities and improve for the future. Edited by Dr. Mansour Al Qubeissi. (InTechOpen. London. ISBN 978-1-78984-284-5) (2020) https://doi.org/10.5772/intechopen.91686

[2] B.K. Ghosh, I. Saad, K.T.K. Teo, and S.K. Ghosh, Optik 206, 164278 https://doi.org/10.1016/j.ijleo.2020.164278

[3] G. Wisz, I. Virt, P. Sagan, P. Potera, R. Yavorskyi, Nanoscale Research Letters, 12 (1), 253 (2017); https://doi.org/10.1186/s11671-017-2033-9

[4] F.B. Baghsiyahi, A. Akhtar, M. Yeganeh, International Journal of Modern Physics B, 32 (20), 1850207 (2018); https://doi.org/10.1142/S0217979218502077

[5] J.P. Sawant, R.J. Deokate, H.M. Pathan, R.B. Kale, Engineered Science, 13, 51-64 (2021); https://doi.org/10.30919/es8d1147

[6] Y. Zheng, B. Sadeghimakki, E. Piano, S. Sivoththaman, 2019 IEEE 46th Photovoltaic Specialists Conference (PVSC, 2019, June) pp. 1806-1812; https://doi.org/10.1109/PVSC40753.2019.8980483

[7] M.E. Calixto, P.J. Sebastian, R.N. Bhattacharya, R. Noufi, Solar Energy Materials and Solar Cells, 59(1-2), 75-84 (1999); https://doi.org/10.1016/S0927-0248(99)00033-1

[8] A. Bosio, N. Romeo, S. Mazzamuto, V. Canevari, Progress in Crystal Growth and Characterization of Materials, 52(4), 247-279 (2006); https://doi.org/10.1016/j.pcrysgrow.2006.09.001

[9] A.I. Kashuba, H.A. Ilchuk, R.Y. Petrus, B. Andriyevsky, I.V. Semkiv, E.O. Zmiyovska, Applied Nanoscience, 1-8 (2021); https://doi.org/10.1007/s13204-020-01635-0.

[10] P.K.K. Kumarasinghe, A. Dissanayake, B.M.K. Pemasiri, B.S. Dassanayake, Materials Research Bulletin, 96, 188-195 (2017); https://doi.org/10.1016/j.materresbull.2017.04.026

[11] S. Marjani, S. Khosroabadi, M. Sabaghi, Optics \& $\quad$ Photonics $\quad$ Journal $\quad 6(2), \quad 15 \quad$ (2016); https://doi.org/10.4236/opj.2016.62003

[12] L.I. Nykyruy, B.P. Naidych, O.M. Voznyak, T.O. Parashchuk, R.V. Ilnytskyi, Semiconductor Physics, Quantum Electronics and Optoelectronics, 22(2), 156-164 (2019); https://doi.org/10.15407/spqeo22.02.156.

[13] L. Nykyrui, Y. Saliy, R. Yavorskyi, Y. Yavorskyi, V. Schenderovsky, G. Wisz, S. Górny, 2017 IEEE 7th International Conference Nanomaterials: Application \& Properties (NAP) (pp. 01PCSI26-1); https://doi.org/10.1109/NAP.2017.8190161

[14] D. Pegu, J. Deb, D. Paul, U. Sarkar, Computational Condensed Matter, 14, 40-45 (2018); https://doi.org/10.1016/j.cocom.2018.01.001

[15] M. Isik, H.H. Gullu, S. Delice, M. Parlak, N.M. Gasanly, Materials Science in Semiconductor Processing, 93, 148-152 (2019); https://doi.org/10.1016/j.mssp.2019.01.001.

[16] G.A. Il'chuk, V.V. Kusnezh, V.Yu. Rud, Yu.V. Rud, P.Yo. Shapowal, R.Yu. Petrus', Semiconductors, 44(3), 318-320 (2010); https://doi.org/10.1134/S1063782610030085

[17] Z.B. Gutierrez, P. K. G Zayas-Bazán, O. De Melo, D. Moure-Flores, J. A. Andraca-Adame, L. Moreno-Ruiz, H. Martínez-Gutiérrez, S. Gallardo, J. Sastré-Hernández, G. Contreras-Puente, Materials, 11(10), 1788 (2018); https://doi.org/10.3390/ma11101788

[18] I.E. Tinedert, F. Pezzimenti, M.L. Megherbi, $\quad$ A. Saadoune, Optik, 208, 164112 (2020); https://doi.org/10.1016/j.ijleo.2019.164112

[19] L.I. Nykyruy, R.S. Yavorskyi, Z.R. Zapukhlyak, G. Wisz, P. Potera, Optical Materials, 92, 319-329 (2019); https://doi.org/10.1016/j.optmat.2019.04.029

[20] A.A. Ojo, H.I. Salim, O.I. Olusola, M.L. Madugu, I.M. Dharmadasa, Journal of Materials Science: Materials in Electronics, 28(4), 3254-3263 (2017); https://doi.org/10.1007/s10854-016-5916-0

[21] R.Y. Petrus, H.A. Ilchuk, A.I. Kashuba, I.V. Semkiv, E.O. Zmiiovska, F.M. Honchar, Journal of Applied Spectroscopy, 87 (1), 35-40 (2020); https://doi.org/10.1007/s10812-020-00959-7 
First-Principles Calculations of Stable Geometric Configuration and Thermodynamic Parameters...

[22] A. Mutalikdesai, S.K. Ramasesha, Thin $\quad$ Solid $\quad$ Films, $\quad 632, \quad 73-78 \quad$ (2017); https://doi.org/10.1016/j.tsf.2017.04.036

[23] W. Kohn, A.D. Becke, R.G. Parr, The Journal of Physical Chemistry, 100 (31), 12974-12980 (1996); https://doi.org/10.1021/jp9606691

[24] M. Tsubaki, T. Mizoguchi, $\quad$ Physical Review $\quad$ Letters, 125 (20) https://doi.org/10.1103/physrevlett.125.206401

[25] http://sites.google.com/a/kdpu.edu.ua/calculationphysics/

[26] W. Kohn J.J. Sham Physical Review,

(1965); https://doi.org/10.1103/physrev.140.a1133

[27] G.B. Bachelet, D.R. Hamann, M. Schlüter, Physical Review $\quad$ B, 26 (8), 4199-4228 (1982); https://doi.org/10.1103/physrevb.26.4199

[28] G.M.J. Barca, C. Bertoni, L. Carrington, D. Datta, N. De Silva, J.E. Deustua, D.G. Fedorov, J.R. Gour, A.O. Gunina, E. Guidez, T. Harville, S. Irle, J. Ivanic, K. Kowalski, S.S. Leang, H. Li, W. Li, J.J. Lutz, I. Magoulas, J. Mato, V. Mironov, H. Nakata, B.Q. Pham, P. Piecuch, D. Poole, S.R. Pruitt, A.P. Rendell, L.B. Roskop, K. Ruedenberg, T. Sattasathuchana, M.W. Schmidt, J. Shen, L. Slipchenko, M. Sosonkina, V. Sundriyal, A. Tiwari, J.L. Galvez Vallejo, B. Westheimer, M. Włoch, P. Xu, F. Zahariev, M.S. Gordon, J. Chem. Phys. 152, 154102 (2020); https://doi.org/10.1063/5.0005188

[29] W.J. Stevens, H. Basch, M. Krauss, J. Chem. Phys. 81, 6026 (1984); https://doi.org/10.1063/1.447604

[30] A.D. Becke. J. Chem. Phys. 98 (2), 1372 (1993); https://doi.org/10.1063/1.464304

[31] C. Lee, W. Yang, R.G. Parr, Phys. Rev. B. 37 (2), 785 (1988); https://doi.org/10.1103/PhysRevB.37.785

[32] D. Freik, T. Parashchuk, B. Volochanska, Journal of Crystal Growth, 402, 90-93 (2014); https://doi.org/10.1016/j.jcrysgro.2014.05.005

[33] B. Naidych, T. Parashchuk, I. Yaremiy, M. Moyseyenko, O. Kostyuk, O. Voznyak, Z. Dashevsky, L. Nykyruy, Journal of Electronic Materials, 50(2), 580-591 (2021); https://doi.org/10.1007/s11664-020$\underline{08561-5}$

[34] https://www.webelements.com/hydrogen/thermochemistry.html

[35] N.S. Priya, S.S.P. Kamala, V. Anbarasu, S.A. Azhagan, R. Saravanakumar, Materials Letters, 220, $161-164$ (2018); https://doi.org/10.1016/j.matlet.2018.03.009

[36] B. Li, J. Xu, W. Chen, D. Fan, Y. Kuang, Z. Ye, W. Zhou, H. Xie, Journal of Alloys and Compounds, 743, 419-427 (2018); https://doi.org/10.1016/j.jallcom.2018.02.021

[37] R.P. Beyer, M.J. Ferrante, R.V. Mrazek, J. Chem.Thermodynamic, 15 (9), $827-834 \quad$ (1983); https://doi.org/10.1016/0021-9614(83)90088-5

[38] O. Vigil, I. Riech, M. Garcia-Rocha, O. Zelaya-Angel, Journal of Vacuum Science \& Technology A: Vacuum, Surfaces, and Films, 15 (4), 2282-2286 (1997); https://doi.org/10.1116/1.580735

[39] R. Lozada-Morales, O. Zelaya-Angel, Thin Solid Films, 281, 386-389 (1996); https://doi.org/10.1016/00406090(96)08621-X

[40] O Zelaya-Angel, $\quad$ H. Yee-Madeira, $\quad$ R. Lozada-Morales, $\quad$ Phase $\quad$ Transirions. $\quad 70, \quad 11-17$ (1999); https://doi.org/10.1080/01411599908241336

[41] O. Zelaya-Angel, J.J. Alvarado-Gil, R. Lozada-Morales, H. Vargas, A. Ferreira da Silva, Applied Physics Letters, 64(3), 291-293 (1994); https://doi.org/10.1063/1.111184

[42] M. Kim, H. Kim, S. Lee, S. Sohn, Molecular Crystals and Liquid Crystals, 564(1), 162-168 (2012); https://doi.org/10.1080/15421406.2012.691737

[43] B.B. Kadhim, M.A. Abdulsattar, A.M. Ali, International Journal of Modern Physics B, 33(16), 1950163 (2019); https://doi.org/10.1142/S0217979219501637

[44] C.G. Torres-Castanedo, J. Márquez-Marín, R. Castanedo-Pérez, G. Torres-Delgado, M.A. Aguilar-Frutis, S. Arias-Cerón, O. Zelaya-Ángel, Journal of Materials Science: Materials in Electronics, 31 (19), 16561-16568 (2020); https://doi.org/10.1007/s10854-020-04211-y 
Ж. Олексин ${ }^{1}$, Б. Найдич ${ }^{1}$, О. Чернікова ${ }^{2}$, Л. Глова ${ }^{3}$, Я. Огороднік ${ }^{4}$, М. Соловйов $^{5}$, В. Ващинський ${ }^{5}$, Р. Яворський ${ }^{1}$, Г. Ільчук ${ }^{5}$

\title{
Розрахунки із перших принципів стабільної геометричної конфігурації та термодинамічних параметрів тонкоплівкових конденсатів кадмій сульфіду
}

\author{
${ }^{1}$ Прикарпатський національний університет імені Василя Стефаника, Івано-Франківськ, Украйна \\ ${ }^{2}$ Криворізький національний університет, Кривий Ріг, Украӥна, hmchernikova@gmail.com \\ ${ }^{3}$ Radiation Monitoring Devices, inc. USA, yogorodnik@rmdinc.com \\ ${ }^{4}$ College of Natural Sciences, Rzeszow University, Pigonia 1, 35-959 Rzeszow, Poland \\ ${ }_{5}^{5}$ Національний університет «Львівська політехніка», Львів, Україна
}

Розглянуто тонкоплівкові шари $\mathrm{CdS}$, отримані методом відкритого випаровування у вакуумі та запропоновано кластерні моделі для розрахунку кристалічної, зонної структури та термодинамічних параметрів. Визначено термодинамічні параметри енергії утворення $\Delta E$, ентальпії утворення $\Delta H$, енергії Гіббса $\Delta G$, ентропії $\Delta S$ та питомих теплоємностей при сталому тиску $C_{P}$ та об'ємі $C_{V}$ для кубічної та гексагональної кристалографічних модифікацій. Із аналізу температурних залежностей енергії Гіббса для сфалеритної та вюрцитної фаз визначено стабільну кристалічну структуру для кадмій сульфіду.

Ключові слова: кадмій сульфід, кристалічна структура, вюрцит, термодинамічні параметри. 